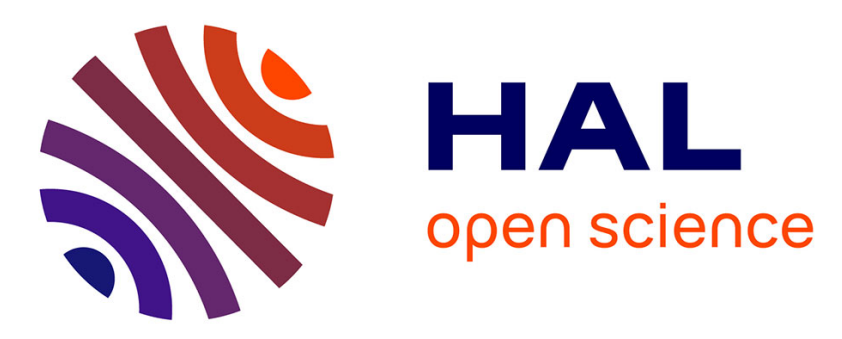

\title{
Impacts of different agricultural practices on the biodiversity of microarthropod communities in arable crop systems
}

\author{
Jérôme Cortet, Damien Ronce, Nicole Poinsot-Balaguer, Christian \\ Beaufreton, André Chabert, Philippe Viaux, Jorge Paulo Cancela de Fonseca
}

\section{To cite this version:}

Jérôme Cortet, Damien Ronce, Nicole Poinsot-Balaguer, Christian Beaufreton, André Chabert, et al.. Impacts of different agricultural practices on the biodiversity of microarthropod communities in arable crop systems. European Journal of Soil Biology, 2002, 38 (3-4), pp.239-244. 10.1016/S11645563(02)01152-4 . hal-03218304

\section{HAL Id: hal-03218304 \\ https://hal.science/hal-03218304}

Submitted on 5 May 2021

HAL is a multi-disciplinary open access archive for the deposit and dissemination of scientific research documents, whether they are published or not. The documents may come from teaching and research institutions in France or abroad, or from public or private research centers.
L'archive ouverte pluridisciplinaire HAL, est destinée au dépôt et à la diffusion de documents scientifiques de niveau recherche, publiés ou non, émanant des établissements d'enseignement et de recherche français ou étrangers, des laboratoires publics ou privés. 


\title{
Impacts of different agricultural practices on the biodiversity of microarthropod communities in arable crop systems
}

\author{
Jérôme Cortet ${ }^{\mathrm{a}, *}$, Damien Ronce ${ }^{\mathrm{b}}$, Nicole Poinsot-Balaguer ${ }^{\mathrm{a}}$, Christian Beaufreton ${ }^{\mathrm{c}}$, \\ André Chabert ${ }^{\mathrm{c}}$, Philippe Viaux ${ }^{\mathrm{b}}$, Jorge Paulo Cancela de Fonseca ${ }^{\mathrm{d}}$ \\ anstitut Méditerranéen d'Ecologie et Paléoécologie, Université de Provence, Centre Saint Jérôme, case 462, \\ 13397 Marseille cedex 20, France

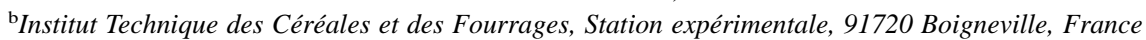 \\ ${ }^{\mathrm{c}}$ Association de Coordination Technique Agricole, Chambre d'agriculture, 4 place Gensoul, 69287 Lyon cedex 2, France \\ ${ }^{\mathrm{d}}$ CNRS et Université Paris7-Denis Diderot, Laboratoire de Biologie Végétale et d'Ecologie Forestière, 77300 Fontainebleau, France
}

Received 14 August 2000; accepted 22 May 2001

\begin{abstract}
Two crop production systems, which differ on tillage and pesticides, were compared for biodiversity of soil microarthropod communities. A biodiversity index, which integrates different structure and density parameters (abundance, taxonomic richness, taxonomic diversity, coenotic diversity) was used. Results showed a greater biodiversity in minimum tillage systems compared to deep tillage systems. Pesticides seemed to be only a second order factor of variance on microarthropod biodiversity.
\end{abstract}

Keywords: Microarthropods; Biodiversity; Low imput systems; Tillage; Pesticides; Arable crops

\section{Introduction}

Soil microarthropods are often used as bioindicators of agricultural soil quality. Studies have shown the impacts of soil compaction [7,12-14], and others have compared different agricultural production systems, such as integrated, organic or conventional systems $[1,5,6,8]$. But, whereas differences in abundance or biomass are often explored, few studies have presented results on diversity.

This paper presents results of a comparison of the impact of two agricultural arable crop practices on soil microarthropod communities in two French regions, using a biodiversity index.

\footnotetext{
* Corresponding author

* Jerome.cortet@univ-montp3.fr (J. Cortet).
}

\section{Materials and methods}

\subsection{Study site and description of cultivation systems}

The study was carried out on the experimental farm of the Association de Coordination Technique Agricole (ACTA), situated in Courseulles (Calvados, Normandy), on which 10 different fields had been regularly monitored for 8 years previously, to compare two different agricultural systems: "Conventional" and "Integrated" (Table 1).

The climate is typically oceanic. During the study period, from January to June 1997 , the minimum temperatures were recorded in January (with a mean of $-3.7{ }^{\circ} \mathrm{C}$ for the first week), and the maximum in June (with a mean of $16.7^{\circ} \mathrm{C}$ for the first week). Precipitation was irregular, being low in early-mid spring (11.6 and $11 \mathrm{~mm}$, respectively, in March and April, which correspond to the minimum), and relatively high in late spring-early summer (50 $\mathrm{mm}$ in June, which is the maximum reached). The site overlies typical Jurassic calcareous bedrock. 
Table 1

Soil cultivation and pesticides on the Courseulles site, for each field studied in 1997 and all the fields from 1991 to 1995

\begin{tabular}{lllllll}
\hline $\begin{array}{l}\text { Fields } \\
\text { (year of harvesting) }\end{array}$ & System & Tillage & $\begin{array}{l}\text { Other soil } \\
\text { cultivation }\end{array}$ & $\begin{array}{l}\text { Herbicides } \\
\left(\mathrm{kg} \mathrm{ha}^{-1}\right)\end{array}$ & $\begin{array}{l}\text { Insecticides } \\
\left(\mathrm{kg} \mathrm{ha}^{-1}\right)\end{array}$ & $\begin{array}{l}\text { Fungicides } \\
\left(\mathrm{kg} \mathrm{ha}^{-1}\right)\end{array}$ \\
\hline P1 Grand Parc (1997) & Con & Present & C, SPH & 0.64 & 0.15 & 1.09 \\
& Int & Absent & C, SPH & 1.85 & 0.071 & 0.31 \\
P3 Les Carfolands (1997) & Con & Present & SH, SPH & 0.58 & 0.084 & 1.96 \\
& Int & Absent & SH, SPH & 1.85 & 0 & 0.71 \\
P4 Le Meslier (1997) & Con & Absent & C, SPH & 0.64 & 0.14 & 1.09 \\
& Int & Absent & C, H, SPH & 1.05 & 0 & 0.31 \\
Mean of ten fields (1991-1995) & Con & Variable & Variable & 1.70 & 0.23 & 1.94 \\
& Int & Variable & Variable & 1.53 & 0.087 & 0.88 \\
\hline
\end{tabular}

Con: Conventional ; Int: Integrated; C: cultivating ; SPH: seeding + power harrows ; SH: sugarbeets harvesting ; H: harrowing

Three different fields were chosen for the study (Table 1). They were all sown with winter wheat (Triticum aestivum L.) during the sampling period. However, each had been cropped the year before with a different crop: fibre flax (Linum usitatissimum L.) at Grand Parc (P1), Sugar beet (Beta vulgaris var. altissima) at Carfolands (P3), spring protein peas (Pisum sativum L. arvense) at Le Meslier (P4).

Soil physico-chemical analyses showed a different texture for P1 compared to the other fields, with twice as much sand and only half the amount of silt.

Each field had been divided into two parts for 8 years, one for each system. However, each system in each field was maintained independently. Thus, sometimes, the "Integrated" part may have received more pesticides than the "Conventional" part. An average amount of pesticides, based on five cropping years and the 10 fields, has been calculated: even if the amount of herbicides is equivalent between the two systems, the amount of insecticides and fungicides is considerably reduced in the "Integrated" system. Furthermore, in 1997, the amount of herbicides was greater in the "Integrated" than in the "Conventional" system. On the other hand, in 1997, tillage was reduced in the "Integrated" systems, except in P4 that showed no differences in tillage between the systems but a supplementary harrowing in the "Integrated" one (Table 1).

\subsection{Sampling methodology and statistical evaluation}

For each system in the three chosen fields, and for each sampling date, five soil cores $(5 \mathrm{~cm}$ diameter and $10 \mathrm{~cm}$ deep) were collected. Sampling was carried out monthly from January to June 1997, corresponding to the winter wheat growing season. After extraction using the Berlese method [2], animals were identified, counted and classified into five different taxa: oribatid mites, gamasid mites, "other mites", collembolans and "other arthropods".

The significant differences in abundance between the systems were assessed for each field and each taxon, on each sampling date (using the Mann-Whitney test, Statview software, SAS foundation).
Then, for each field, "Conventional" and "Integrated" systems were compared using the $\Delta V$ index of biodiversity for four different taxa: oribatid mites, collembolans, "other mites" (all the mites excluding oribatid mites) and "other arthropods". A complete description of the calculation of this index can be found in [3]. The main features are as follows:

$$
\Delta V=\left[V(x)+V(S)+V(n)+V\left(H^{\prime} x\right)+V\left(H^{\prime} y\right)\right] / 5
$$

where $x$ is the abundance of the taxonomic group; $S$ is the number of taxonomic groups; $n$ is the number of samples containing the taxon; $\mathrm{H}^{\prime} \mathrm{x}$ is the taxonomic diversity index; and $\mathrm{H}^{\prime} \mathrm{y}$ is the coenotic diversity index; and:

$$
V m=(C m-I m) /(C m+I m)
$$

where $\mathrm{Cm}$ is the parameter $m$ value in the Conventional system (for example $\mathrm{H}^{\prime} \mathrm{x}$ ); and $\mathrm{Im}$ is the parameter $m$ value in the integrated system.

If $\mathrm{Cm}=\mathrm{Im}$, no differences can be observed between the two systems. If $\mathrm{Cm}<\mathrm{Im}$, the difference of biodiversity is negative. If $\mathrm{Cm}>\mathrm{Im}$, the difference of biodiversity is positive. Thus, the index ranges between -1 and +1 .

\section{Results}

\subsection{Grand Parc (P1) site}

The greatest population abundance in total microarthropods was in spring, particularly in April and May (Table_d). Significant differences in abundance of microarthropods were observed between the systems, especially concerning oribatid mites, which were more abundant in the "Integrated" compared with the "Conventional" system, from January to April. "Other mites" were also more abundant in the "Integrated" system in April. Total microarthropod populations confirmed these differences in January, February and April. However, in May, differences could not be 
Table 2

Mean abundance and standard deviation of each taxon in Courseulles. from January to June 1997

\begin{tabular}{|c|c|c|c|c|c|c|c|c|c|c|c|c|}
\hline \multirow[t]{2}{*}{ P1 (Grand Parc) } & \multicolumn{2}{|l|}{ January 1997} & \multicolumn{2}{|c|}{ February 1997} & \multicolumn{2}{|l|}{ March 1997} & \multicolumn{2}{|l|}{ April 1997} & \multicolumn{2}{|l|}{ May 1997} & \multicolumn{2}{|l|}{ June 1997} \\
\hline & Con & Int & Con & Int & Con & Int & Con & Int & Con & Int & Con & Int \\
\hline Collembola & $0.8 \pm 0.84$ & $0.6 \pm 0.55$ & $0.4 \pm 0.55$ & $2 \pm 2.12$ & $1 \pm 1.41$ & $2.6 \pm 1.67$ & $1.8 \pm 2.95$ & $3 \pm 2.55$ & $0.2 \pm 0.45$ & $0.4 \pm 0.55$ & $1.4 \pm 2.19$ & $2 \pm 1.87$ \\
\hline Oribatida & $5 \pm \mathbf{1 . 5 8}$ & $33.8 \pm 33.3$ & $10.6 \pm 9.86$ & $37 \pm 25.1$ & $5.2 \pm 4.87$ & $23.8 \pm 12.8$ & $21.4 \pm 17.3$ & $59.4 \pm 32.1$ & $20.2 \pm 9.42$ & $40.6 \pm 31.9$ & $1.2 \pm 2.17$ & $1.2 \pm 1.3$ \\
\hline Gamasida & $3.6 \pm 5.27$ & $2 \pm 3.08$ & $1.8 \pm 1.3$ & $2.4 \pm 1.14$ & $1 \pm 0.71$ & $1.2 \pm 1.1$ & $5.6 \pm 5.86$ & $5.2 \pm 3.56$ & $2.2 \pm 1.79$ & $1.4 \pm 2.61$ & 0 & $0.2 \pm 0.45$ \\
\hline Other mites & $2 \pm 3.94$ & $7.8 \pm 6.38$ & $6.2 \pm 4.82$ & $6.8 \pm 6.76$ & $7 \pm 5.43$ & $5.8 \pm 4.76$ & $11.6 \pm 4.16$ & $30.6 \pm 9.89$ & $29.6 \pm 30.6$ & $58 \pm 45.2$ & $42.2 \pm 48.6$ & $10 \pm 4.74$ \\
\hline Other arthropods & $0.8 \pm 1.3$ & $0.2 \pm 0.45$ & $0.6 \pm 0.55$ & $1.2 \pm 1.64$ & $2.6 \pm 1.52$ & $1.6 \pm 1.52$ & $1.8 \pm 1.79$ & $2.2 \pm 1.92$ & $1 \pm 1$ & $3.2 \pm 2.39$ & $1.4 \pm 1.52$ & $3 \pm 2.35$ \\
\hline Total & $12.2 \pm 11.7$ & $44.4 \pm 40$ & $19.6 \pm 9.3$ & $49.4 \pm 28.4$ & $16.8 \pm 10.7$ & $35 \pm 15.4$ & $42.2 \pm 23$ & $100 \pm 43.4$ & $53.2 \pm 27$ & $104 \pm 76.1$ & $46.2 \pm 49.8$ & $16.4 \pm 7.02$ \\
\hline \multirow[t]{2}{*}{ P3 (Les Carfolands) } & \multicolumn{2}{|l|}{ January 1997} & \multicolumn{2}{|c|}{ February 1997} & \multicolumn{2}{|l|}{ March 1997} & \multicolumn{2}{|l|}{ April 1997} & \multicolumn{2}{|l|}{ May 1997} & \multicolumn{2}{|l|}{ June 1997} \\
\hline & Con & Int & Con & Int & Con & Int & Con & Int & Con & Int & Con & Int \\
\hline Collembola & $1 \pm 1.73$ & $0.4 \pm 0.89$ & $0.4 \pm 0.55$ & $0.8 \pm 0.45$ & $3.2 \pm 3.9$ & $1.6 \pm 0.89$ & $13.6 \pm 12.5$ & $13.8 \pm 12.6$ & $8.4 \pm 5.59$ & $0.8 \pm 1.3$ & $4.2 \pm 3.56$ & $15.8 \pm 19.9$ \\
\hline Oribatida & $2.2 \pm 1.48$ & $13 \pm 5.79$ & $11.2 \pm 10.8$ & $10.2 \pm 5.76$ & $17.8 \pm 8.17$ & $9.2 \pm 5.81$ & $10 \pm 3.24$ & $16.4 \pm 9.91$ & $24 \pm 20.6$ & $1.6 \pm 1.52$ & $0.6 \pm 0.89$ & $0.6 \pm 0.89$ \\
\hline Gamasida & $1 \pm 0.71$ & $1.4 \pm 2.61$ & $0.6 \pm 0.89$ & $2.2 \pm 2.68$ & $3 \pm 4.64$ & $1.6 \pm 1.95$ & $7.2 \pm 5.12$ & $20.2 \pm 28.9$ & $10.6 \pm 13.1$ & $1 \pm 0.71$ & $1 \pm 0.71$ & $0.4 \pm 0.55$ \\
\hline Other mites & $0.8 \pm 1.1$ & $2.8 \pm 2.68$ & $3.2 \pm 2.68$ & $7 \pm 6.2$ & $4 \pm 3$ & $32.8 \pm 23.3$ & $17.8 \pm 5.22$ & $24.6 \pm 13$ & $9.2 \pm 7.19$ & $2.6 \pm 1.95$ & $25.8 \pm 17.6$ & $17 \pm 16.4$ \\
\hline Other arthropods & $0.2 \pm 0.45$ & $0.4 \pm 0.55$ & $0.8 \pm 1.1$ & $1.2 \pm 1.1$ & $1.6 \pm 1.52$ & $2.2 \pm 1.3$ & $3.2 \pm 3.11$ & $8 \pm 5.79$ & $0 \pm 0$ & $1.8 \pm 0.84$ & $2 \pm 2$ & $2.2 \pm 2.77$ \\
\hline Total & $5.2 \pm 2.95$ & $18 \pm 11.3$ & $16.2 \pm 10.5$ & $21.4 \pm 8.59$ & $29.6 \pm 10.4$ & $47.4 \pm 30.2$ & $51.8 \pm 20.5$ & $83 \pm 33.8$ & $52.2 \pm 24.9$ & $7.8 \pm 2.17$ & $33.6 \pm 20.7$ & $36 \pm 37.8$ \\
\hline \multirow[t]{2}{*}{ P4 (Le Meslier) } & \multicolumn{2}{|l|}{ January 1997} & \multicolumn{2}{|l|}{ February } & \multicolumn{2}{|l|}{ March } & \multicolumn{2}{|l|}{ April } & May & & \multicolumn{2}{|l|}{ June 97} \\
\hline & Con & Int & Con & Int & Con & Int & Con & Int & Con & Int & Con & Int \\
\hline Collembola & $2.4 \pm 1.52$ & $4.6 \pm 4.39$ & $1.4 \pm 0.89$ & $2.6 \pm 2.07$ & $4.6 \pm 4.56$ & $1.4 \pm 1.95$ & $3.8 \pm 2.39$ & $3.2 \pm 2.59$ & $0.6 \pm 0.89$ & $0.4 \pm 0.55$ & $4 \pm 2.83$ & $6 \pm 4.69$ \\
\hline Oribatida & $39.8 \pm 28.2$ & $35.8 \pm 15.8$ & $33.8 \pm 15.9$ & $59.2 \pm 28.5$ & $16.2 \pm 3.83$ & $23 \pm 12.5$ & $17.2 \pm 5.17$ & $53.4 \pm 23.6$ & $22.2 \pm 27.3$ & $30.2 \pm 18.7$ & $1.6 \pm 0.55$ & $0.8 \pm 0.84$ \\
\hline Gamasida & $2.2 \pm 1.3$ & $3.8 \pm 2.17$ & $2 \pm 1$ & $9.8 \pm 6.06$ & $3.8 \pm 4.09$ & $9.2 \pm 4.76$ & $6 \pm 1.58$ & $7 \pm 1$ & $6.4 \pm 2.97$ & $5.2 \pm 1.92$ & $1 \pm 1.73$ & $0.6 \pm 0.89$ \\
\hline Other mites & $28.8 \pm 15.9$ & $1.4 \pm 1.52$ & $13.6 \pm 4.28$ & $5 \pm 2.12$ & $13.8 \pm 2.28$ & $9.6 \pm 3.51$ & $35.8 \pm 17$ & $8.6 \pm 4.62$ & $39.8 \pm 46.9$ & $6.8 \pm 4.66$ & $15.2 \pm 20.2$ & $33.6 \pm 14.6$ \\
\hline Other arthropods & $0.6 \pm 0.89$ & $0.8 \pm 0.84$ & $1.8 \pm 2.68$ & $1 \pm 1.22$ & $1.2 \pm 1.64$ & $4.2 \pm 2.95$ & $2 \pm 1.87$ & $3 \pm 1.58$ & $0.8 \pm 1.1$ & $0.8 \pm 1.3$ & $1.8 \pm 1.1$ & $9.4 \pm 18.8$ \\
\hline Total & $73.8 \pm 31.5$ & $46.4 \pm 19$ & $52.6 \pm 19.9$ & $77.6 \pm 30.7$ & $39.6 \pm 13.3$ & $47.4 \pm 17.6$ & $64.8 \pm 19.8$ & $75.2 \pm 27$ & $69.8 \pm 76$ & $43.4 \pm 24$ & $23.6 \pm 19.5$ & $50.4 \pm 21.1$ \\
\hline
\end{tabular}

Con: Conventional system; Int: Integrated system. Significant differences between the systems (Con and Int) are expressed in bold characters $($ Mann-Whitney test with $P<0.05)$ 


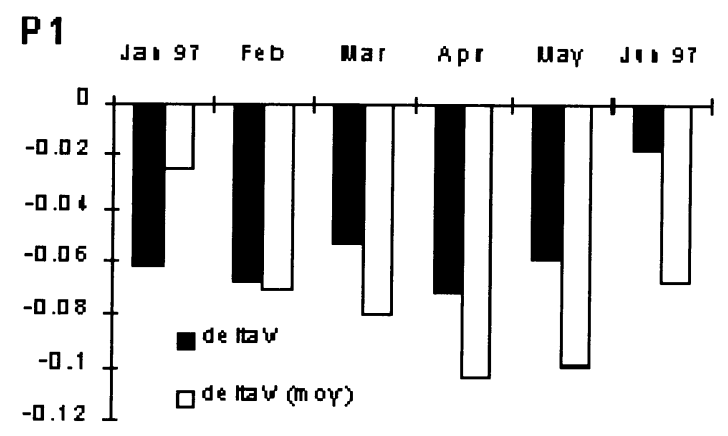

P3

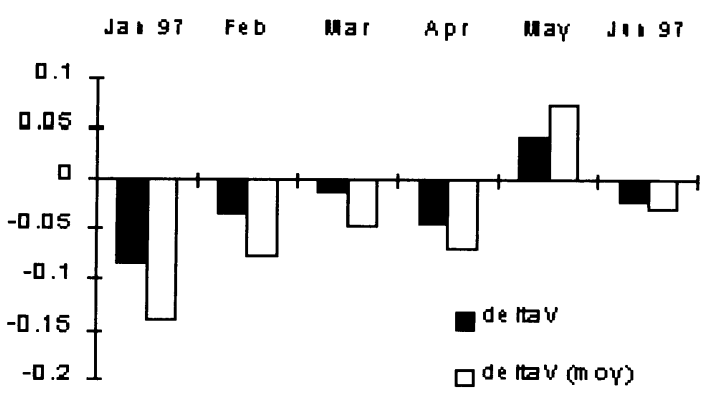

\section{$P_{4}$}

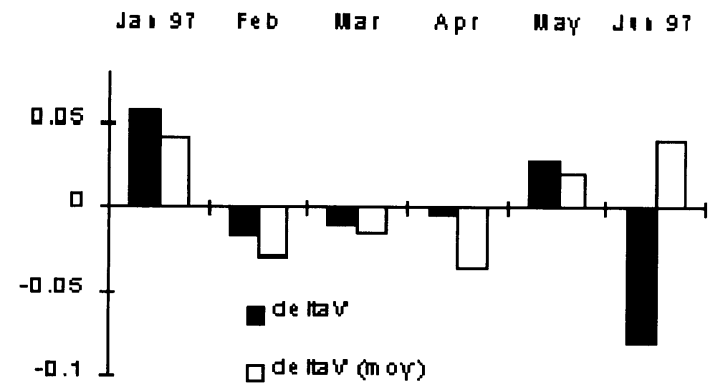

Fig. 1. The $\Delta V$ index of biodiversity for "Integrated" and "Conventional" systems for each sampled field (P1, P3, P4) in Courseulles, from January to June 1997 . The $\Delta V$ : each parameter is calculated as the sum of means; $\Delta V$ moy: each parameter is calculated as the mean of sums. If Conventional<Integrated, the difference of biodiversity is negative. If Conventional > Integrated, the difference of biodiversity is positive.

observed, and in June, greater abundance of total microarthropods was observed in the "Conventional" system.

From January to June, the index $\Delta V$ indicated greater biodiversity in the "Integrated" compared to the "Conventional" system (Fig. 1). The greater differences between the systems were apparent in April and May.

\subsection{Les Carfolands (P3) site}

As in P1, the greatest abundance in total microarthropods was observed during spring, particularly in April (Table_2). Significant differences were observed between abundance of microarthropods, with greater abundance of oribatid mites in the "Integrated" system in January, and of other mites in February and March. The total microarthropod numbers were also significantly greater in the "Integrated" system in January. Significant differences between the systems could not be observed in April and June. However, in May, a greater population abundance was observed in the "Conventional" compared to the "Integrated" system for oribatids and total microarthropods.

These results were confirmed by $\Delta V$ values, which indicated higher biodiversity in the "Integrated" system for all months, except May (Fig. 1). The most marked difference in biodiversity between systems occurred in January.

\subsection{Le Meslier (P4) site}

A high level of abundance of microarthropods occurred in spring (April and May), as in the other fields, and also in winter (Table 2) January and February). There were a few significant differences in abundance between the systems during the study. In January the abundance of "other mites" was greater in the "Conventional" than in the "Integrated" system. Similar results were observed in April. However, in April, the abundance of oribatids was greater in the "Integrated" than in the "Conventional" system. In June the total abundance of microarthropods was greater in the "Integrated" than in the "Conventional" system.

The $\Delta V$ index indicated greater overall biodiversity under "Conventional" than "Integrated" management in January and May, but was slightly greater in the "Integrated" than in the "Conventional" from February to April (Fig. 1). Biodiversity was similar for the two systems in June.

\section{Discussion}

Any disturbance or stress imposed on a system interacts with environmental factors, which can vary with time and space. Thus, different factors, independent of agricultural practices, influence microarthropod populations in these arable crops. This is the case for climatic factors. Thus, abundance variations occurred over time in Courseulles, with a logical increase in population densities during spring, when precipitation and temperature were high and favourable for greater biological activity.

However, even if these factors can influence and cause fluctuations in microarthropod populations, biodiversity differences between the systems are often quite stable, with, except for some months in P4 and May in P3, greater 
biodiversity in the "Integrated" compared to the "Conventional" system.

Results observed at Courseulles might be explained by tillage, which is known to decrease microarthropod abundance $[12,14]$. Thus, in January, which is the sampling date closest to the last soil cultivation, the biodiversity was greater in the "Integrated" system in P1 and P3 than in the "Conventional" one, but the opposite was observed in P4 site. These results are logical, since in P1 and P3, soil cultivation, particularly tillage, was more intense in the "Conventional" than in the "Integrated" system, and in P4, soil cultivation was more intense in the "Integrated" system than in the "Conventional" one. Furthermore, tillage is known to increase soil compaction that might have negatively affected microarthropod populations [13].

At the Courseulles site, pesticides could involve variations in function of two factors: the pesticide spraying history of each field and the diversity of microarthropod reactions to any given pesticide. Indeed, the different pesticides can have different effects on soil invertebrates [4]. Furthermore, even if qualitative and quantitative pesticide differences can be observed between the systems of each field, the pesticide spraying calendar should be taken into account when looking at the effects on microarthropods. Indeed, even if we can observe, from a general point of view, that pesticide use was less important in the "Integrated" than in the "Conventional" system (see the mean amount of pesticides used on ten fields during 5 years), this is not always true for each year. Thus, in 1997, the overall quantities of herbicides used were greater in the "Integrated" than in the "Conventional" system. These remarks are also valuable for each season of culture, since each system for each field was conducted independently from the other systems of other fields. Thus, for some sampling dates, particularly during spring when many pesticides were also sprayed in the "Integrated" system, the biodiversity was not always greater in the "Integrated" system, as it was observed in P3 and P4.

Physical modifications caused by soil cultivations (particularly tillage), are often considered as the more intensive $[6,10,11]$. At the Courseulles site, it was very difficult to differentiate and appreciate the role of each disturbance factor (soil cultivation and pesticides). Indeed, the P1 field, which had the largest biodiversity differences between the systems, was also the field that had the largest differences between the systems, concerning both pesticide use and soil cultivations. But, the impact of herbicides seemed to be low, since in 1997, even with higher quantities of herbicides used in "Integrated" compared to that in "Conventional", the biodiversity is still higher in the "Integrated" system. However, analytical experiments, including a separate study of pesticides and soil cultivations would be necessary to understand the relative impacts of these two factors.

The previous types of culture should also be taken into account. At the Courseulles site, all of the sampled fields had a different previous culture that could explain in part the variations in microarthropod populations between the fields. These results agree with those obtained by Jagers op Akkerhuis et al. [9], concerning the influence of type of culture and rotation on soil microarthropods. Indeed, they showed that microarthropod populations were different under different types of cultures.

\section{Acknowledgements}

This project was performed under the ACTA programme: « Recherche d'indicateurs biologiques permettant d'évaluer l'effet de techniques et systèmes de production sur l'activité et la diversité biologique des sols ». This programme is financed by «Ministère de l'Agriculture et de la Pêche » and « Ministère de l'Education Nationale de la Recherche et de la Technologie ».

\section{References}

[1] L. Brussaard, L.A. Bouwman, M. Geurs, J. Hassink, K.B. Zwart, Biomass, composition and temporal dynamics of soil organisms of a silt loam soil under conventional and integrated management, Netherlands J. Agric. Sci. 38 (1990) 283-302.

[2] A. Berlèse, Apparacchio per raccogliere presto ed in gran numero piccoli arthropodi, Redia 2 (1905) 85-89.

[3] J.P. Cancela da Fonseca, S. Sarkar, On the evaluation of spatial diversity of soil microarthropod communities, Eur. J. Soil Biol. 32 (1996) 131-140.

[4] J. Cortet, N. Poinsot-Balaguer, Impact de produits phytopharmaceutiques sur les microarthropodes du sol en culture de maïs irrigué: approche fonctionnelle par la méthode des sacs de litière, Can. J. Soil Sci. 80 (2000) 237-249.

[5] B.M. Dekkers, P.A. Van der Werff, P.A.M. Van Amelsvoort, Soil Collembola and Acari related to farming systems and crop rotations in organic farming, Acta Zool. Fennica 195 (1994) 28-31.

[6] A. El Titi, U. Ipach, Soil fauna in sustainable agriculture: results of an integrated farming system at Lautenbach, FRG, Agr. Ecosyst. Environ. 27 (1989) 561-572.

[7] P.F. Hendrix, R.W. Parmelee, D.A. Crossley Jr, D.C. Coleman, E.P. Odum, P.M. Goffman, Detritus food webs in conventional and no-tillage agroecosystems, Bioscience 36 (1986) 374-380.

[8] N.R. Hulugalle, L.A. Lobry de Bruyn, P. Entwistle, Residual effects of tillage and crop rotation an soil properties, soil invertebrate numbers and nutrient uptake in an irrigated vertisol sown to cotton, Appl. Soil Ecol. 7 (1997) 11-30.

[9] G.A.J.M. Jagers op Akkerhuis, F. De Ley, H.J.C. Zwetsloot, J.F. Ponge, L. Brussaard, Soil microarthropods (Acari and Collembola) in two crop rotations on a heavy marine clay soil, Rev. Ecol. Biol. Sol 25 (1988) 175-202.

[10] D. Mallow, R.J. Snider, L.S. Robertson, Effects of different management practices on Collembola and acarina in corn production systems, Pedobiologia 28 (1985) 115-131. 
[11] J.C. Moore, R.J. Snider, L.S. Robertson, Effects of different management practices on Collembola and acarina in corn production systems. I. The effects of no-tillage and atrazine, Pedobiologia 26 (1984) 143-152.

[12] D.A. Neher, M.E. Barbercheck, Diversity and function of soil mesofauna, in: W.W. Collins, C.O. Qualset (Eds.), Biodiversity in Agroecosystems, CRC Press, New York, 1999, pp. 27-47.
[13] S. Schrader, M. Lingnau, Influence of soil tillage and soil compaction on microarthropods in agricultural land, Pedobiologia 41 (1997) 202-209.

[14] M.A. Sabatini, L. Rebecchi, C. Cappi, R. Bertolani, B. Fratello, Long-term effects of three different continuous tillage practices on Collembola populations, Pedobiologia 41 (1997) 185-193. 